\title{
First records of chewing lice (Phthiraptera: Menoponidae) in Pacific migratory shorebirds wintering in Ecuador
}

\author{
Primeiros registros de malófagos (Phthiraptera: Menoponidae) em aves marinhas \\ migratórias do Pacífico invernada no Equador
}

Ben Haase ${ }^{1,2}$; Juan José Alava ${ }^{2,3 *}$

\author{
${ }^{1}$ Museo de Ballenas, Salinas, Ecuador \\ ${ }^{2}$ Fundación Ecuatoriana para el Estudio de Mamíferos Marinos - FEMM, Guayaquil, Ecuador \\ ${ }^{3}$ School of Resource \& Environmental Management, Faculty of Environment, Simon Fraser University - SFU, \\ Burnaby, British Columbia V5A 1S6, Canada
}

Received October 7, 2013

Accepted January 22, 2014

\begin{abstract}
Chewing lice were collected from small shorebirds (Charadriformes: Scolopacidae) overwintering in foraging grounds of coastal Ecuador. On 27 occasions at least one louse (3.7\%) was collected from six host species. Based on external morphological characters, at least two species of chewing lice could be preliminary identified (family: Menoponidae), including Actornithophilus umbrinus (Burmeister, 1842) and Austromenopon sp. A. umbrinus was found in the Western Sandpiper (Calidris mauri), Least Sandpiper (C. minutilla), Stilt Sandpiper (C. himantopus), Semipalmated Plover (Charadrius semipalmatus) and Wilson's phalarope (Phalaropus tricolor), while Austromenopon sp. is presumably the first record collected from the Surfbird (Aphriza virgata). These findings indicate that the distribution of these chewing lice species covers at least the regions around the equator (latitude $0^{\circ}$ ) until the Arctic in the north, but probably also includes the entire winter distribution area of the host species. This is the first study of chewing lice from Ecuador's mainland coast and more research is required to understand the host-parasite ecology and ectoparasitic infection in shorebirds stopping over the region.
\end{abstract}

Keywords: Chewing lice, Actornithophilus umbrinus, Austromenopon sp., shorebirds, Ecuador.

\section{Resumo}

Piolhos mastigadores foram coletados em pequenas aves marinhas (Charadriformes: Scolopacidae) que invernavam na zona de forrageamento na costa do Equador. Em 27 ocasióes, pelo menos um piolho (3,7\%) foi coletado em seis espécies de hospedeiros. Com base em caracteres morfológicos externos, pelo menos duas espécies de piolhos mastigadores foram preliminarmente identificados (família: Menoponidae), incluindo Actornithophilus umbrinus (Burmeister, 1842) e Austromenopon sp. A. umbrinus foi encontrado em Pilrito-miudo (Calidris mauri), Pilrito-anão (C. minutilla), Pilrito-pernilongo (C. himantopus), Borrelho-semipalmado (Charadrius semipalmatus) e o Falaropo de Wilson (Phalaropus tricolor), enquanto Austromenopon sp. é, presumivelmente, o primeiro registro coletado na AveSurfista (Aphriza virgata). Esses resultados indicam que a distribuição dessas espécies de piolhos mastigadores abrange pelo menos as regiōes ao redor do Equador (latitude $0^{\circ}$ ) até o Ártico, no Norte, mas provavelmente também inclui toda a área de distribuição de inverno essas espécies hospedeiras. Este é o primeiro estudo de piolhos de aves marinhas da área continental do Equador e mais pesquisas são necessárias para compreender a ecologia parasita-hospedeiro e ectoparasitose destas aves que invernam na regiáo.

Palavras-chave: Piolhos mastigadores, Actornithophilus umbrinus, Austromenopon sp., pássaros marinos, Equador.

\footnotetext{
${ }^{*}$ Corresponding author: Juan José Alava

School of Resource \& Environmental Management, Simon Fraser University,

8888 University Drive, Burnaby, British Columbia V5A 1S6, Canada

e-mail: jalavasa@sfu.ca
} 


\section{Introduction}

Bird chewing lice are obligate, permanent ectoparasites with a direct life cycle passed entirely on the body of the host, feeding mainly on feathers and dermal debris although some specie feed on blood (CLAYTON; WALTHER, 2001; CLAYTON; DROWN, 2001; CLAYTON et al., 2008). Louse eggs are glued to the host's feathers or hair and when hatched lice spend little, if any, time off the body of the host. Transmission to new hosts takes place primarily during periods of direct contact, such as between parent hosts and their offspring in the nest (CLAYTON; DROWN, 2001). Studies on chewing lice and infection in aquatic and shorebirds overwintering in tropical-equatorial areas are scarce as more research has been focused on temperate and subtropical areas of the northern and southern hemispheres (YANEZ; CANARIS, 1988; PALMA, 1999; PALMA; JENSEN, 2005; PRICE et al., 2003a; GONZÁLEZ et al., 2005). To the best of our understanding, the nearest studies in the equatorial zone of the Southeastern Pacific Ocean region and South America are those done by Clayton and Price (1989), who discovered a new species of Menoponidae from a Barred Forest-Falcon, Micrastur ruficollis (Falconidae) in Peru and more recent studies on ectoparasites (e.g., chewing lice, mite) conducted in Galapagos hawks, Buteo galapagoensis (WHITEMAN; PARKER, 2005), and Galapagos finches, e.g., Geospiza spp., Certhidea olivacea (VILLA et al., 2013).

In 1991, a banding program was started along the continental coast of Ecuador with the aim to know more about the wintering ecology of pacific migratory shorebirds. By means of additional information, featherlice were collected from small shorebirds (Charadriformes, Scolopacidae) captured during field work and banding. In this note, we contribute with preliminary knowledge and findings on chewing lice based on the first specimens collected in shorebirds from coastal Ecuador.

\section{Materials and Methods}

The sampling was conducted in Pacoa, a site located just north of the village of San Pablo (02 $\left.{ }^{\circ} 10^{\prime} \mathrm{S}, 80^{\circ} 45^{\prime} \mathrm{W}\right)$, Santa Elena Peninsula Province, in coastal Ecuador. The study area consisted of a $1 \mathrm{~km}$ long, non-tidal mudflat near the artificial salt lakes. The mudflats are flooded with outflow (containing many organic and non-organic items) from shrimp larvae laboratories which are located directly behind the Pacific shoreline. Over a length of several kilometers, the mudflats vary in width between 20 to $100 \mathrm{~m}$ wide. The prevailing weather conditions throughout the year are very stable, with a soft breeze coming from the southwest, usually less than 3 on Beaufort scale.

More than 2000 hours of shorebird banding were carried out, with a total number of 6500 birds (smaller waders) captured with mistnets and banded between 1991 and 1999. It must be kept in mind that during that time period no bird was ever checked thoroughly to see how many lice could be found. However, between October 1997 and December 1998, efforts were deployed to improve the scouting and collection of lice physically by hand and on 27 occasions at least one parasite was directly collected from six different host species to identify lice species (see Table 1). Thus, for the purpose of this note, we focus our findings on the data collected from 1997 to 1998. Basic biometric data were obtained before the birds were equipped with an aluminum band and according to the inter-American standard method, two color flags (i.e. for Ecuador: light green over red) were placed on the tibia (HAASE, 2011). Since the Western Sandpiper, Calidris mauri, was the banding project's target species, there was a special interest for collecting lice from this species, and secondly from additional host species. Lice samples were initially saved in formalin $9 \%$, while the rest was preserved in ethanol $40 \%$, then cleared in $\mathrm{K}(\mathrm{OH}) 10 \%$ and fixed in Canada balsam based on the slide-mounting technique described by Palma (1978). Taxonomic identification at the family and species levels was done using a dissecting microscope (Olympus) and following the lice identification key by Price et al. (2003b).

\section{Results and Discussion}

The collected ectoparasites were identified as feather lice (Order: Phthiraptera; soborder: Amblycera; family: Menoponidae). At forehand and in the field it looked as the samples were from the same louse species with dark brown coloration, but at least two different species were found, including Actornithophilus umbrinus (Burmeister, 1842) and Austromenopon sp. The former was found to dwell in the Western Sandpiper (Calidris mauri), Least Sandpiper (C. minutilla), Stilt Sandpiper (C. himantopus), Semipalmated Plover (Charadrius semipalmatus) and Wilson's phalarope (P. tricolor), while Austromenopon sp. is likely to be the first record collected from the Surfbird (Aphriza virgata). The external characters of the Menoponidae lice collected are illustrated in Figure 1. The specimens examined exhibited small, wingless and flattened bodies with a mean length of $2.0 \mathrm{~mm}$, ranging from $1.9 \mathrm{~mm}$ to $2.1 \mathrm{~mm}$. The antenae and feet are very short, while their eyes are very much reduced; there is a small thorax and two chewing mandibles; the tarsi have one or two articulations with a

Table 1. Field data of live-captured and banded shorebirds, from which lice samples were collected in 1997 and 1998 at San Pablo (Santa Elena Peninsula Province), Ecuador.

\begin{tabular}{llcc}
\hline \multicolumn{1}{c}{ Collection dates } & \multicolumn{1}{c}{ Host species } & Bird ages & Lice collected \\
\hline 19 October 1997 - 26 December 1998 & C. mauri (Western Sandpiper) & First year -Adult & 16 \\
3 December 1997 - 4 November 1998 & C. minutilla (Least Sandpiper) & First year -Adult & 6 \\
16 September 1998 & Phalaropus tricolor (Wilson's Phalarope) & First year & 1 \\
14 November 1998 & Calidris himantopus (Stilt Sandpiper) & First year & 1 \\
2 November 1998 & Charadrius semipalmatus (Semipalmated Plover) & Adults & 2 \\
12 September 1998 & Aphriza virgata (Surfbird) & First year & 1 \\
\hline
\end{tabular}




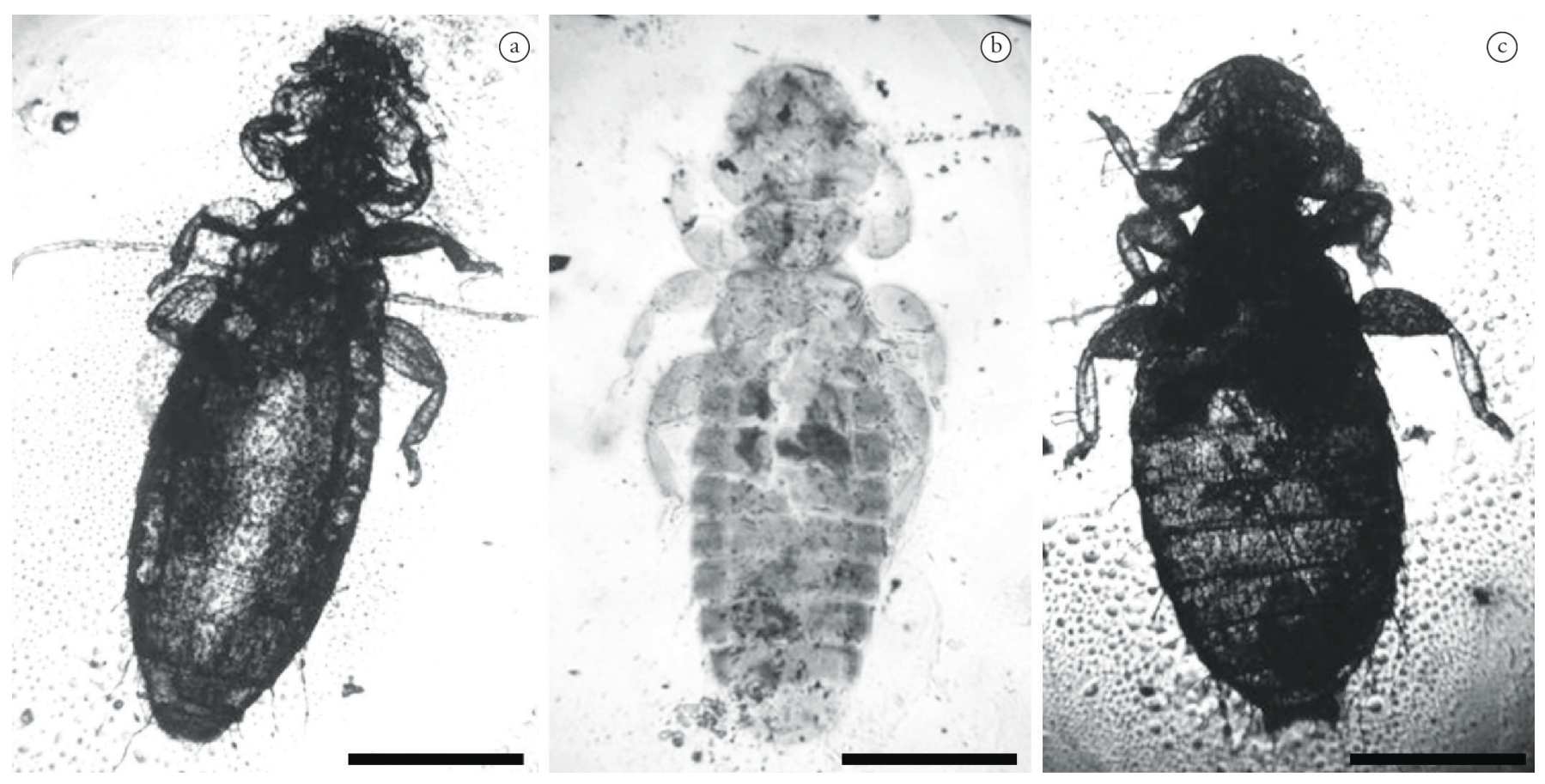

Figure 1. Species of parasitic lice (Insecta: Phthiraptera: Menoponidae) collected from Pacific shorebirds in coastal Ecuador: (a-b) Actornithophilus umbrinus found in the Wilson's Phalarope (P. tricolor), Semipalmated Plover (C. semipalmatus) and in three species of sandpipers: Western Sandpiper (C. mauri), Least Sandpiper (C. minutilla), and Stilt Sandpiper, (C. himantopus); (c) Austromenopon sp. found in the Surfbird (A. virgata). $\mathrm{Bar}=0.50 \mathrm{~mm}$.

single nail (Figure 1a-c). Both adult and immature parasites were found. The latter of a similar, but smaller size and with a much paler body color.

Details of the hosts from which lice were collected from 1997 to 1998 are shown in Table 1. At least one louse was collected from the following seven host species: in only one occasion from Wilson's Phalarope Phalaropus tricolor, Stilt Sandpiper Calidris himantopus, Semipalmated Sandpiper C. pusilla and Surfbird Aphriza virgata. Based on their plumage, these hosts were all aged as first-year birds. Two more lice were collected from two adult Semipalmated Plover Charadrius semipalmatus; five from the Least Sandpiper Calidris minutilla (i.e. 1 adult, 5 first-yr) and sixteen from Western Sandpiper Calidris mauri (i.e. 16 first-yr). From a total of 27 cases, more than $85 \%$ of the birds were first year birds. This represents the mean value of the ratio for first-year to adult birds during the sampling period in the study area. Other shorebird species in which lice were commonly observed, but not collected were Sanderling (C. alba), Short-billed Dowitcher (Limnodromus griseus), and Spotted Sandpiper (Actitis macularia), as well as on two local breeding species: Wilson's Plover (C. wilsonius) and Snowy Plover (C. alexandrinus).

The first five shorebirds species of host handled in the field, shown in Figure 2 from the top to the bottom, occur frequently in each other's presence using fairly the same type of wetland, and seemed to share the same lice species ( $A$. umbrinus), as shown in Figure 1a, b. Yet, it draws the attention that what turns out to be a different, undetermined species (Austromenopon sp.) was collected from a particular host (A. virgata), which is seldom - if ever- seen on mudflats; instead, this shorebirds

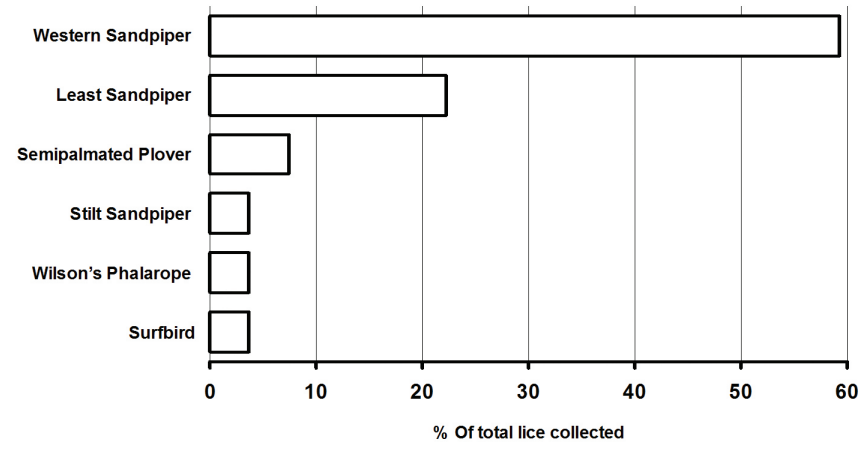

Figure 2. Relative prevalence (\%) of lice in six shorebird species sampled at San Pablo, coastal Ecuador, in 1997 and 1998.

strongly prefers the rough, intertidal, rocky habitat (HAASE, 2011). The species $A$. umbrinus has been found in several other Calidris species, including $C$. acuminata, and C. canutus from New Zealand (PILGRIM; PALMA, 1982; PALMA, 1999) and C. alpina, C. canutus and C. maritima from the Faroe Islands (PALMA; JENSEN, 2005). A. umbrinus was also collected from migrating Wilson's phalarope (P. tricolor) in El Paso, Texas (YANEZ; CANARIS, 1988). The genus Austromenopon sp. is commonly found in shorebirds belonging to the Charadriidae and Scolopacidae families, including some species under the genera Vanellus, Charadrius, Numenius, Limosa, Arenaria, Coenocorypha, Calidris, Tringa (PILGRIM; PALMA, 1982; PALMA, 1999; PALMA; JENSEN, 2005), but it has not been collected from Aphriza. 
These findings indicate that the distribution of Menoponidae species (i.e. A. umbrinus; Austromenopon sp.) covers at least the latitudes from the tropical area around the equator to Alaska and the Canadian Arctic, but probably also includes the entire winter distribution area of the host species. Amongst the captured host species there is one Surfbird. This species is not rare along the Ecuadorean coast, but only rather common in specific habitat which consists of rocky intertidal coastline and this was probably the first one ever caught in Ecuador (HAASE, 2011). The sample from this bird was very different from those that were commonly found on all the other host species.

It drew the attention that many birds had lice, but in terms of unhealthy feather condition or unusual weight, there were no signs at all to state that there was a relationship between the presence of lice on a host and its physical condition, even thought chewing lice can have affect the host fitness, feeding mainly on feathers, dermal debris and blood (BOOTH et al., 1993). Interestingly, when lice were found, occasionally one or several secondary feathers were perforated. Usually in the distal third part of a flight feather, halfway between the shaft and the feather edge up to three small round holes $(\varnothing=0.75 \mathrm{~mm})$ per feather could be noticed. It is likely that these holes were caused by lice, although the latter was never found close to the former.

Main subject of this note is to present the first information on feather lice collected in Ecuador. Since the sampling was only to obtain some additional data, interpretation of the information on frequency and selection of host species by the parasites must be done with caution. The predominance of the Western Sandpiper (C. mauri) as a host species is obviously a result of the sampling method. It should not be considered as this species was the most common shorebird species in the study area. However, the Surfbird $A$. virgata is also on the host species list, but its appearance is only occasional. To our knowledge, very few feather lice from shorebirds have been studied and the samples are possibly the first ones ever collected from nearctic shorebirds on their tropical wintering grounds in Ecuador. For any comparison, it would be interesting to collect data from shorebirds on their breeding grounds.

\section{Acknowledgements}

In the first place we would like to thank all the people and volunteers who assisted during the fieldwork. We are gratefully to the Ecuasal Company (Salinas) for allowing the first author to work on their property. We are indebt with Dr. D. González from Universidad de Concepcion for helping in the identification of the lice specimens and the personnel of the Parasitology Lab of the National Institute of Hygiene and Tropical Medicine of Ecuador for allowing us to use their equipment to examine the samples. Thanks to Dr. Gustavo Dominguez, who did the Portuguese-language translation for the abstract. The banding work and the sampling would not have been possible without the financial help of the Canadian Wildlife Service. Especially, the overall support of Dr. R.W. Elner is mostly appreciated. Dr. T. Piersma gave useful comments.

\section{References}

Booth DT, Clayton DH, Block BA. Experimental demonstration of the energetic cost of parasitism in free-ranging hosts. Proc $R$ Soc $B$ 1993; 253(1337): 125-129. http://dx.doi.org/10.1098/rspb.1993.0091

Clayton D, Price RD. Colpocephalum holzenthali n. sp. (Mallophaga: Menoponidae) from the barred forest-falcon Micrastur ruficollis (Falconidae) in Peru. J Parasitol 1989; 75(4): 505-507. PMid:2760761. http://dx.doi.org/10.2307/3282896

Clayton DH, Drown DM. Critical evaluation of five methods for quantifying chewing lice (Insecta: Phthiraptera). J Parasitol 2001; 87(6): 1291-1300. PMid:11780812.

Clayton DH, Walther BA. Influence of host ecology and morphology on the diversity of Neotropical bird lice. Oikos 2001; 94(3): 455-467. http://dx.doi.org/10.1034/j.1600-0706.2001.940308.x

Clayton DH, Adams RJ, Bush SE. Phthiraptera, the Chewing lice. In: Atkinson CT, Thomas NJ, Hunter DB. Parasitic diseases of wild birds. Ames: Wiley-Blackwell; 2008. p. 515-526.

González D, Skewes O, Candia C, Palma R, Moreno L. Estudio del parasitismo gastrointestinal y externo en caiquén Chloephaga picta Gmelin, 1789 (Aves, Anatidae) en la región de Magallanes, Chile. Parasitol Latinoam 2005; 60(1-2): 86-89. http://dx.doi.org/10.4067/ S0717-77122005000100016

Haase BJM. Aves Marinas de Ecuador Continental y Acuáticas de las Piscinas Artificiales de Ecuasal. Aves \& Conservacion, Bird Life InternationalEcuador, and Ecuasal. Guayaquil; 2011.

Palma RL. Slide-mounting of lice: a detailed description of the Canada balsam technique. New Zeal Entomol 1978; 6(4): 432-436. http://dx.doi. org/10.1080/00779962.1978.9722313

Palma RL. Amendments and additions to the 1982 list of chewing lice (Insecta: Phthiraptera) from birds in New Zealand. Notornis 1999; 46(3): 373-387.

Palma RL, Jensen J-K. Lice (Insecta: Phthiraptera) and their host associations in the Faroe Islands. Steenstrupia 2005; 29(1): 49-73.

Pilgrim RLC, Palma RL. A list of the chewing lice (Insecta: Mallophaga) from birds in New Zealand. Notornis 1982; 29(suplement):1-32

Price RD, Hellenthal RA, Palma RL, Johnson KP, Clayton DH. The chewing lice: World checklist and biological overview. Illinois; 2003a. Illinois Natural History Survey Special Publication 24.

Price RD, Hellenthal RA, Palma RL. World checklist of chewing lice with host associations and keys to families and genera. In: Price RD, Hellenthal RA, Palma RL, Johnson KP, Clayton DH. The chewing lice: World checklist and biological overview. Illinois; 2003b. p. 1-448. Illinois Natural History Survey Special Publication 24.

Villa SM, Le Bohec C, Koop JAH, Proctor HD, Clayton DH. Diversity of feather mites (Acari: Astigmata) on Darwin's Finches. J Parasitol 2013; 99(5): 756-762. http://dx.doi.org/10.1645/12-112.1

Whiteman NK, Parker PG. Using parasites to infer host population history: a new rationale for parasite conservation. Anim Conserv 2005; 8(2): 175181. http://dx.doi.org/10.1017/S1367943005001915

Yanez DM, Canaris AG. Metazoan parasite community composition and structure of migrating Wilson's Phalarope, Steganopus tricolor Viellot, 1819 (Aves), from El Paso County, Texas. J Parasitol 1988; 74(5): 754-762 http://dx.doi.org/10.2307/3282250 